\title{
HOSPITALITAS KRISTEN DAN BUDAYA MA'NENE' DI DAERAH LEMPO POTON
}

\author{
Pitriani Padatu \\ Institut Agama Kristen Negeri Toraja \\ Pitrianipadatu2@gmail.com
}

\begin{abstract}
Abstrak:
Negara Indonesia adalah Negara yang merupakan sala satu Negara yang unik, yang memiliki ciri khas yang khusus yang dimana Negara lain tidak memilikinya, Negara Indonesia memiliki ciri khusus yang majemuk yang memiliki berbagai macam suku, bahasa, agama, dan juga budaya, Negara Indonesia juga dikenal memiliki berbagai macam-macam warisan budaya yang sangat kaya yang memiliki keunikan tersendiri yang dimana Indonesia memiliki daerah yang kaya akan budaya it, daerah yang memiliki berbagai ragam budaya itu adalah daerah Tanah Toraja yang dimana warisannya berhasil dibuat menjadi sebuah bagian dari pariwisata yang dimana seluruh dunia telah mengunjunginya, Daerah toraja memiliki berbagaimacam budaya salah satunya adalah budaya Ma'nene' budaya ini salah satu budaya yang unik di Indonesia yang tepatnya di Toraja Utara Sulawesi selatan. Budaya ma'nene' ini adalah suatu kegiatan yang dilakukan oleh suku toraja untuk melakukan ritual mengganti pakaian jasad dengan pakaian yang baru, juga menjemur jasad yang sudah lama meningga. Hospitalitas Kristen dan budaya adalah suatu kehidupan yang harus di miliki oleh setiap manusia karena segalah sesuatu yang ada di daerah toraja atau masyarakat itu di tentukan oleh budaya yang di anut masyarakat itu sendiri.

Kata Kunci : Hospitalitas Kristen, budaya, Ma'nene'

\section{Pendahuluan:}

Negara Indonesia adalah salah satu Negara yang unik, yang memiliki ciri khas yang unik yang dimana tidak dimiliki oleh Negara yang lain , Negara Indonesia memiliki masyarakat yang majemuk yang memiliki berbagai macam suku bangsa, bahasa, agama dan budaya. Suku di Indonesia hidup berdampingan dan latar belakang yang sangat berbeda dengan berkembangnya penduduk di Indonesia itu membuat Negara Indonesia menjadi sala satu urutan ke empat dari Negara cina, india, dan amerika serikat. Indonesia juga merupakan Negara yang kaya akan berbagi macam budaya yang di miliki daerah yang ada di Indonesia yang di mana daerah di Indonesia memiliki budaya dan adat yang tersendiri, berbagai budaya yang ada di daerah itu adalah salah satu hasil cipta daerah itu sendiri dan karsa masyarakat yang didalamnya memenuhi kebutuhan hidup kebudayaan itu yang mencangkup pengetahuan, keyakinan, susila, serta hokum adat yang biasanya di lakukan di daerah itu. Setiap
\end{abstract}


wilayah atau daerah di Indonesia memiliki tradisi yang berbeda-beda yang dimana adalah keagamaan yang bersifat ritual ${ }^{1}$

Negara Indonesia memiliki daerah atau wilayah yang memiliki bergagai macam budaya dan adat juga kekayaan warisan budaya yang sebagian menjadi pariwisata. Daerah yang memiliki semua kekayaan itu adalah daerah Tanah Toraja, daerah Toraja ini memiliki keunikan tersendiri, daerah ini juga memiliki berbagai macam budaya/adat yang salah satunya adalah Ma'nene' yang di mana budaya ini memiliki keunikan tersendiri di Indonesia yang dimana tepatnyanya di daerah Toraja Utara Sulawesi selatan, di wilayah toraja utara tepatnya di lempo poton Ma'nene' ini adalah sala satu kegiatan yang di lakukan 1 kali dalam jangka 3 tahun dan kegiatan ini di lakukan di setiap bulan agutus. Kegiatan ma'nene' ini merupakan suatu penghormatan kepada orang tua yang telah lama meninggal dan juga merupakan suatu penghormatan kepada leluhur, budaya ma'nene' ini mencerminkan bahwa penting bagi setiap orang bahwa betapa pentingnya hubungan kekeluargaan dalam wilayah toraja dan bagian dari ma'nene' ini adalah memperkenalkan anggota-anggota keluarga yang mudah baik itu cucu-cucunya kepada leluhurnya ${ }^{2}$

\section{Tujuan dan Manfaat:}

Tujuan dari paper ini adalah untuk meningkatkan Hospitalitas Kristen terhadap budaya ma'nene' bagi masyarakat toraja

\section{Pembahasan:}

\section{Budaya Ma'nene'}

budaya ma'nene' merupakan atau ritual yang dimana kegiatan ini adalah membersikan kuburan, mengganti pakaian, jasad, dan juga menjemur jasad, kegiatan ini dilakukan sebagian dari memperkenalkan cucu-cucunya kepada leluhurnya yang tela lama meninggal dunia. Meskipun budaya ini sudah banyak daerah yang tidak melakukan namun di beberapa daerah masih melakukannya salah satunya adalah daerah Lempo Poton yang di mana di lakukan 3 tahun sekali dan pelaksanaannya di bulan agustus.

Di lembang Lempo Poton budaya ma'nene' dilakukan 3tahun sekali dan acara ma'dinene' di lakukan di bulan agustus, masyarakat Lempo Poton melakukan ritual ma'nene' ini dilakukan dalam jangka 1 minggu yang di mana hari pertama ma'bukka' (membuka pintu kubur), dan hari ke 2 sampai hari keenam adalah hari di mana warga lempo poton masseroi (membersikan), mantanan bunga (tanam bunga) magpapanggan/ma'patole ( memberikan sirih dan rokok kepada orang meninggal dengan cara menaro di depan pintu kubur ) magpapakei, (mengganti baju mayat), manggalloi ( menjemur mayat), dan pada bulan agustus orang mulai membibit padi (manggambo' pare ) yang di sebut dengan sebutan pare nene' dan setelah membibit pare (manggambo') masyarakat mulai membikin kuburan (manggaraga

\footnotetext{
${ }^{1}$ Daniel Fajar Panuntun, Jimmi Pindan, Pute, Lisdayanti Anita Manggalik, "model dialog imajiner Entas-Entos untuk mengkomunikasikan Kristus kepada Masyarakat Tengger, " visio Del: jurnal Teologi Kristen 2,no.1 (2020):84-104.

${ }^{2}$ http://www.indonesiakarya.com/jelajah-indonesia/manene-sebuah-proses-adat-bentuk-penghormatanterhadap-para-leluhur
} 
kaburu'/patane) yang di mana biasanya masyarakat lempo poton menyebutnya dengan sebutan ditallu rarai, pada hari pertama setelah orang membuka pintu kubur atau di sebut dengan ( ma'bukka') masyarakat lempo poton terlebih dulu memotong kerbau sebagai symbol ma'garri'/ma'palaku yang dimana memberi tanda pada batu yang akan di buat kubur liang, setelah dua hari setelah itu masyarakat lempo poton memotong babi yang menandakan bahwa suda siap untuk membuat liang (kaburu'/patane) setelahnya itu apabilah kuburan tersebut telah selesai masyarakat lempo poton mengadakan suatu acara yang dimana di sebut massabu dan acara itu di lakukan di tempat dimana liang yang telah di buat itu berada dan masyarakat lempo poton membawa makanan ke trempat tersebut yang di mana ada nasi, dan juga pa'piong setelah acara massabu selesai pintu kubur (patane) akan di tutup dan diberi nama dengan sebutan (liang/patane) karena apabila belum melaksanakan kegiatan massabu maka kuburan baru (liang) masi di angga rumah. Pada saat itu jugta masyarakat lempo poton tidak melakukan suatu kegiatan baik itu acara duka (rambu solo') syukuran rumah, pernikahyan ( rambu tuka'), pembuatan rumah, berkebun, kesawa dl, masyarakat lempo poton tidak di ijinkan melakukan semua kegiatan tersebut di larangkan oleh masyarakt lempo poton, akan tetapi setelah pare nene' di panen semua kegiatan seperti kedukaan dan syukuran (rambu solo' dan rambu tuka') masyarakat lempo poton kembali di ijinkan untuk melakukan kegiatan tersebut, pada saat panen padi telah selesai maka padi kembali di simpan ke atas lumbung (alang) setelah padi (pare) di simpan di atas lumbung "(alang) masyarakat lempo poton kembali tidak di ambil lagi dari atas apabila kegiatan manene' belum selesai atau mantutu' kuburu' setelah selesai masyarakat lembang lempo poton kembali berkumpul atau orang lempo poton menamakannya ma'kombongan membicarakan siapa saja yang akan membawa pare lapu' ( tedong ) kerbau karena orang itulah yang akan pertama membuka kuburan, maka masyarakat yang lain akan membuka kuburan (magbukka) masing-masing, pada saat acara ma'nene' berlangsung masyarakat lempo poton sangat di larang dan di tekankan sekali untuk tidak mengenakan pakaian hitam pada saat pergi ma'nene' karena dalam masyarakat lempo pton ma'nene' bukanlah suatu kegiatan duka (rambu solo') atau syukuran (rambu tuka') karena budaya mma'nene' ada di gtenga-tenga antara rambu solo' dan rambu tuka', pada saat kegiatan ma'nene' tgelah terlaksana apabilah orang lempo poton ada yang melakukan pembuatan rumah maka kegiatan itu di berhentikan selama kegiatan ma'nene' berlaksana dan apabila ada masyarakat lempo poton yang memiliki orang meninggal di atas rumah atau tomate yan g masi ada di atas rumah tidak di perkenankan untuk membicarakan kegiatan kapan acara penguburannya dan itu di sebut di nanna bangpa dolo. Setelah liang suda di buka masyarakat lempo poton mulai mengangkat mayat dari dalam kubur dan menjemur dan menggan ti pakaian mayat itu dan membersikan liang itu ada pun yang hanya di pakekan sarung karena nenek di balun. Setelah semuanya telah di jemur dan di bersikan mayat (nene') kembali di masukkan kedalam liang apabilah ada orang yang mendapat pinang yang utuuh di depan liang itu artinya bahwa "tangpaissan pa tu ana'na na matemo tu to matuanna " (anaknya belum tahu apa-apa orang tuanya meninggal " jadio orang tersebut baru akan memotong kerbau pada acara ma'nene' .

Satu hari sebelum liang (kuburan ) di tutup masyarakat lempo poton serentak memotong babi dan kerbau, apabila ada yang tidak sanggup untuk membeli kerbau akan pergi membawa uang entah itu $100,200,300$, atau lebih kepada orang yang akan membeli kerbau maka itu di sebut suda termasuk suda membeli kerbau. Masyarakat lempo poton memotong babi dan kerbau untuk di makan untuk hari esoknya, dan paginya orang memotong kerbau ebelum pergi mantutu' liang (tutup kuburan ) kemudian 
orang yang pergi menutup liang membawa sedik daging kerbau sebagai pa'pakandean. Setelahnya itu masyarakat lempo poton mengadakan suatu ibadah di suatu tempat tertentu (to'rante) . setelah itu kegiatan ma'nenek di katakana sudah selesai.

Makna dari budaya ma'nene' ini adalah mencerminkan bahwa betapa pentingnya hubungan kekeluargaan meskipun itu telah di pisahkan. Budaya ma'nene' ini juga sebagai suatu kegiatan dimana masyarakat lempo poton akan di perkenalkan dengan anggota keluarga dengan para leluhur yang telah lama meninggal dunia, ma'nene' ini sekarang di lakukan melalui pemahaman kekristenan yang dimana di sertai ibadah, dalam kekristenan budaya ma'nene' tidaklah seperti upacara ma'nene' aluk todolo . ${ }^{3}$

\section{Hospitalitas Kristen}

Hospitalitas merupakan perwujutan dari hokum kasih yang mengajarkan bahwa mengasihi sesame harus seperti mengasihi diri sendiri. Hospitality berasal dari kata latin hospitalitas, yang di mana dari kata hopes, yang uniknya bisa bermakna baik "tuan rumah" maupun "orang asing". Bahkan kata hopes merupakan bentuk lain dari kata hostis, yang juga berarti "musuh" maka dari sinilah nkita menemukan kata bahasa inggris hostility, "permusuhan" dari kata hopes juga ini kita menemukan kata hospital yang bermakna ruang tamu, penginapan yang tentunya masyarakat keramah-keramah dan sambutan hangat .

Dalam Alkitab, hospitalitas juga menjadi sebuah tema yang sangat penting. Dalam budaya Israel dalam timur tengah pada umumnya merupakan kewajiban muliah, bahkan utama untuk menyambut seorang tamu dengan penuh penghormatan dan kehangatan. Seperti Abraham yang ketika melihat tiga orang asing berdiri di depannya, dengan tegesa-gesa berlari dari pintu kemahnya menyongsong mereka lalu sujudlah ia sampai ketanah lalu mengambil seekor anak lembu yang empuk dan baik dagingnya dan memberikan kepada seorang bujangannya lalu seorang ini mengelolahnya (kejadian 2:1-8), juga seperti Lot yang bahkan rela memberikan anak-anak perempuannya sebagai ganti para tamunya yang hendak di gagahi oleh orang-orang dari kota Sodom (kejadian 19:1-9) hal yang tidak masuk akal kita sekarang, akan tetapi hanya bisa di mengerti dalam kerangka pemahaman hospitality masyarakat Timur tengah.Namun dalam pemahaman iman kristiani, tema hospitalitas menjadi lebih penting lagi, karena bukan hanya sekedar kewajiban kultural saja, melainkan sebuah konsekuensi iman. Hospitalitas adalah cara oreangorang Kristen menyatakan hospitalitas Allah dalam Tuhan Yeus Kristus, karena itu di dalam gereja hospitalitas bukan sekedar sebuah program, kegiatan, apalagi kalau hanya sekedar bertujuan berahmatamah dengan pengunjung kebaktian dengan tujuan agar kelak ia mau menjadi anggota gereja, seperti yang berlaku dalam industry jasa.

Sebagaimana di katakana oleh Diana Butler-Bass, seorang teolog Kristen, hospitalitas bukanlah sebuah program atau satu jam khusus dalam hidup pelayanan jemaat. Hospitalitas adalah jantung dari cara hidup kristiani symbol yang hidup dari ketuhanan dalam Allah. Sebagai orang Kristen maka kita bersama-sama mmembangun dan menjadikan hospitalitas sebagai jantung dari hidup pelayanan kita , ada banyak hal yang bersama-sama kita pelajari dan lakukan sebagai komunitas satu keluarga besar juga akan dilakukan yang dirasa pentin g untuk menciptakan atmosfer yang mendukung dan membangun

\footnotetext{
${ }^{3}$ Wawancara denga KALA' pada tanggal, 11 april 2021
} 
hospitalitas kususnya dalam pertemuan-pertemuan kita baik dalam ibadah hari minggu maupun kegiatan kegiatan lainnya. Mari bersama kita saling menyambut, bersama juga kita menyambut siapapun yang Tuhan hadirkan dalam hidup persekutuan kita seperti bagaimana Kristus sudah menyambvut kita dalam kasih-Nya. ${ }^{4}$

\section{Kesimpulan :}

Pada umumnya budaya yang hidup pada suatu daerah atau suda di anut masyarakat di daerah itu adalah merupakan sala satu gambaran dari pola pikir, sifat/tingka laku,dan nilai yang di anut dalam masyarakat. Budaya dan hospitalitas Kristen merupakan suatu kehidupan masyarakat di daerah itu, maka dari situ segala sesuatu yang ada di dalam suatu daerah dan masyarakat itu di tentukan oleh budaya yang dimiliki masyarakat itu sendiri

\section{Referensi:}

Daniel Fajar Panuntun, jimmi Pindan Pute, Lisdayanti Anita Manggalik, "model dialog imajiner EntosEntos untuk mengkomunikasikan Kristus kepada masyarakat Tengger, "visio Del: jurnal Teologi Kristen 2, no 1 (2020):84-104

http://www.indonesiakarya.com/jelajah-indonesia/manene-sebuah-proses-adat-bentuk-penghormatanterhadap-para-leluhur

wawancara dengan KALA' pada tanggal 11 april 2021

http://hospitalitasselisip.com

\footnotetext{
${ }^{4}$ https://hospitalitasselisip.com
} 